DOI https://doi.org/10.36059/978-966-397-106-3/25-44

\title{
THE PREPARATION OF FUTURE TEACHER FOR THE FORMATION OF THE INTERCULTURAL COMMUNICATIVE COMPETENCY OF PUPILS IN THE PROCESS OF THE STUDY OF FOREIGN LANGUAGE
}

\section{Diachenko M. D.}

\section{INTRODUCTION}

In response of globalization and integration of Ukraine into European environment (educational, economic, cultural, legal, etc.), the role of communication in various spheres of social life has increased, that focuses on the need for the development of culture of dialogue among pupils in the process of the study of foreign language, in particular English. The skill of dialogue communication is the basis of human understanding and problem solving. Contemporary realities of the development of society in the context of European integration and globalization processes require special attention to the formation and development of the language personality.

Much attention to the essence of the language personality as the basis for the formation and development of future professional is paid in the research works of educators (I. Bekh, A. Bohush, S. Honcharenko, I. Ziaziun, V. Kremen, S. Rubinshtein. S. Sysoieva, etc.) and linguists (S. Abramovych, Yu. Karaulov, V. Karasyk, V. Redko, O. Selivanova, etc.).

The problem of communicative competence as a component of social and cultural competence is highlighted in the works of such scholars as T. Honchar, K. Moiseienko, L. Fedorova and others. Certain moments of its correlation with social competence were discovered in their scientific researches by N. Kalinina, A. Mudryk, Yu. Polyezhayev and others. The peculiarities of the formation of foreign language competence are outlined in works by V. Barkas, N. Hez, O. Pometun, V. Shliakhova, etc. The process of communicative competency formation was described in research of Ukrainian academicians (S. Doroshenko, Yu. Yemelianov, L. Petrovska, etc.) and foreign scholars (L. Bachman, N. Hez, D. Hymes, M. Canale, R. Milrud, V. Nemushyn, Yu. Passov, M. Swain, etc.). In the framework of 
scientific research, communicative competence is regarded as the notion of a language personality (I. Zymnja); as the individual quality and a certain state of people's consciousness in a group (Yu. Yemelianov); as the necessary level of the experience formation and interpersonal interaction skills that help to perform successfully according to the personal abilities and social status (T. Volfovska), etc.

Personality, thus, is the bearer and speaker of philosophy of life that presents a person as a unique individuality. A person exists in the language, manifests himself/herself in the language, and establishes communication with other people. The effectiveness of language and communication depends on the language culture and the level of speech skills development as well as personal skills. Consequently, every human being is a language personality. This concept reflects the essence of the term "personality", but it covers such a facet as the ability to think and communicate with means of his/her native or foreign language.

\section{The communicative competence of pupils as a sign of language personality}

There are different philosophical definitions of "personality" in varies works. For instance, the authors of philosophical encyclopedic dictionary understand "personality" as the aspects of inner world of a human that are distinguished by his/her uniqueness and openness and realized in self-knowledge and self-creation of a person as well as objectified in artifacts of culture ${ }^{1}$.

Personality is associated with a language; as a recognized psycholinguist O. Leoptiev notes, a language is, first and foremost, a language of an individual. Therefore, without a language there is no personality, as any language cannot exist devoid of a personality. Language is a kind of guide to the world on the way to oneself. A person can realize and understand himself / herself and the world, and, accordingly, can be actualized only through a language, due to the ability to communicate, to master a huge number of verbal and nonverbal signs ${ }^{2}$.

${ }^{1}$ Соломаха А.В. Взаємозв'язок світу, етносу та мови (до питання про мовну картину світу). Науковий часопис НПУ ім. М. П. Драгоманова. Серія № 8. Філологічні науки (мовознавство і літературознавство). 2005. Вип. 1. С. 117-121.

2 Леонтьев А.А. Психолинвистика и личность. Основы психолингвистики. Санкт-Петербург, 2003. С. 280-282. 
According to reference materials, personality is defined as "a person", in the broadest sense, it is concrete, integral human individuality in the unity of his / her natural social skills; in the narrower, philosophical sense "a person" is an individual as a subject of social activity, whose properties are determined by the specific historical conditions of society ${ }^{3}$.

A language personality is a medium of linguistic consciousness that is articulated through verbal behavior. In psychological studies, a language personality is defined as "a form of existence of individual, cognitive consciousness of an intelligent person, as a person who can communicate and is a social being"4. A language personality is an individual who exists in a language environment, where there are norms and stereotypes that are established in a language in forms of linguistic units and contexts of texts ${ }^{5}$.

According to V. Kunicyna, V. Pogol'sha, language culture begins with self-perception of language identity of the speaker. It originates and develops when native speakers who can use literary language care about their oral and written language performance, they care about perception of their communicative activities in various social environments as well as in the context of other languages ${ }^{6}$.

The competence (as a specially structured (organized) set of knowledge, skills and attitudes that are acquired during the learning process) is as an integrated characteristic of personality quality, a productive unit formed through experience, knowledge, skills, attitudes, behavioral reactions ${ }^{7}$.

In the research works of S. Bodnar competence is a general ability and readiness for productive activity, a productive unit formed through experience, knowledge, skills, attitudes, behavioral reactions ${ }^{8}$.

${ }^{3}$ Великий тлумачний словник сучасної української мови/уклад. і голов. ред. В. Т. Бусел. Київ ; Ірпінь: ВТФ «Перун», 2009. 736 с., с. 243.

4 Зимняя И.А. Ключевые компетентности как результативно-целевая основа компетентностного подхода в образовании. Москва: Исследовательский центр проблем качества подготовки специалистов, 2004. 40 с., с. 23.

5 Карасик В.И. Речевое поведение и типы языковых личностей. Массовая культура на рубеже XX-XXI веков: Человек и его дискурс. Москва: Азбуковник, 2003. 368 c., c. 8.

${ }^{6}$ Куницына В.Н., Казаринова Н.В., Погольша В.М. Межличностное общение : учебник для вузов. Санкт-Петербург : Питер, 2001. 544 с., с. 9.

7 Компетентнісний підхід у сучасній освіті: світовий досвід та українські перспективи / за заг. ред. О. В. Овчарук. Київ : «К.І.С.», 2004. 112 с.

Боднар С.П. Термінологічний аналіз понять «компетенція» i «компетентність» у педагогіці: сутність та структура. Освіта $i$ управління. 2007. T. 10. № 2. C. 93-99. 
The competence is based on knowledge, intellectually and personally predetermined social and professional life human ${ }^{9}$, the readiness and ability of the individual to use theoretical knowledge and practical experience to solve individual problems ${ }^{10}$, the ability of a person (specialist) to realize his human potential for professional activity $^{11}$.

It should be noted that term "competency" is wider than the category "competence". This term is also defines as awareness of abilities and skills to perform certain professional functions ${ }^{12}$. The frame of competency is the knowledge, cognitive skills, practical skills, emotions, values, ethics and motivation ${ }^{13}$.

The competency is the sum of skills and abilities needed for effective professional activities - the ability to analyze, the ability to foresee the consequences of professional activities and the ability to use information $^{14}$. The competency is an individual characteristic that exist in numerous forms such as the high level of skills, the modus of personal self-realization (habit, way of life, devotion). It is defined as a summary of the individual's self-development, a form of manifestation of abilities ${ }^{15}$.

As for that communicative competence, then there are different approaches to interpreting the communicative competence in the scientific world:

- as a sum of knowledge about norms and rules of conducting communication acts - dialogues, debates, negotiations ${ }^{16}$;

9 Зимняя И.А. Ключевые компетентности как результативно-целевая основа компетентностного подхода в образовании. Москва : Исследовательский центр проблем качества подготовки специалистов, 2004. 40 с., с. 13.

${ }^{10}$ Кенжебеков Б. Т. Сущность и структура профессиональной компетентности специалиста. Высшая школа Казахстана. 2002. № 2. С. 171.

${ }^{11}$ Татур Ю.Г. Компетентностный подход в описании результатов и проектировании стандартов высшего профессионального образования. URL: http://technical.bmstu.ru/istch/komp/tatur_II.psd.

12 Маркова А.К. Психология профессионализма. Москва: Знание, 1996. 308 с., c. 31 .

13 Настільна книга педагога / упорядники: Андрєєва В.М., Гигораш В.В. Харків : Основа, 2006. 352 с.

14 Професійна освіта: словник / уклад. С.У. Гончаренко та ін. / за ред. Н.Г. Ничкало. Київ, 2000. 380 с.

15 Зязюн І.А. Філософія поступу і прогнозу освітньої системи. Педагогічна майстерність : проблеми, пошуки, перспективи : монографія. Київ ; Глухів : РВВ ГАПУ, 2005. С. 10-18, с. 17.

16 Бех І.Д. Особистісно-зорієнтоване виховання : навч.-метод. посіб. Київ : I3MH, 1998. 204 c. 
- as a possession of complex communicative skills and abilities, the formation of adequate skills in new social structures, knowledge of cultural norms and restrictions in communication, knowledge of customs, traditions, etiquette in the field of communication, educatedness, orientation in communicative means, inherent in the national mentality that is expressed within a particular profession;

- as a system of internal resources necessary for effective communicative action in a definite range of situations of interpersonal interaction $^{17}$;

- as a language skills, interaction with people, teamwork skills, and possession of various social roles (A. Khutorsky) ${ }^{18}$;

- as a system of internal resources of effective interaction: communication positions, roles of stereotypes, settings, knowledge, abilities, skills (I. Cherezova) ${ }^{19}$;

- as a certain level of personal and professional experience in interacting with others used by an individual in order to function successfully within the professional community and society in the framework of his abilities and social status; as a complex ability of a person whose content is determined by the activity of a specialist and the functionality of language and speech; (M. Vasilik) ${ }^{20}$;

- as a skills, ability to solve communication tasks, actualize the goals of communication using a language ${ }^{21}$;

- as a human ability to organize interpersonal space in the process of initiative and active communication with people (Yu. Yemelianov) ${ }^{22}$;

- as one of the main components of professional readiness, which includes knowledge of the ways of purposeful use of language means for solving communication problems; high level of native and foreign

17 Жуков Ю.М. Тренинг как метод совершенствования комуникативной компетентности : дисс. д-ра психол. наук : 19.00.05. Москва, 2003. 356 с.

18 Хуторской А.В. Ключевые компетенции как компонент личностноориентированной парадигмы образования. Народное образование. 2003. № 2. C. $58-64$.

19 Черезова I.O. Комунікативна компетентність як інтегральна якість особистості. Науковий вісник Херсонського державного університету. Серія: «Психологічні науки». 2014. Вип. 1. Т. 1. С. 103-107.

${ }^{20}$ Основы теории коммуникации : учебник / под ред. М.А. Василика. Москва : Гардарики, 2003. 615 с.

21 Tinsley Royal L. Guidelines for college and University programs in translator training. URL: http://www.adfl.org/cgi-shl/docstudio/docs.pl?adfl_login\&xurl.

${ }^{2}$ Емельянов Ю.Н. Теория формирования и практика совершенствования коммуникативной компетентности. Санкт-Петербург, 1999. 403 с. 
languages awareness; possession of communication culture, knowledge of national culture, mentality, knowledge of information and computer technologies, personal readiness, which ensures the cooperation and interaction of the staff ${ }^{23}$;

- as the ability to solve problems and readiness for his professional role in one or another field of activity ${ }^{24}$, etc.

Language personality (according to L. Zasiekina), can be defined as a set of cognitive, emotional and motivational qualities that provide the linguistic competence of a person as a medium of national and cultural environment ${ }^{25}$.

Intercultural competence is defined as the:

- an active component of the personality, aimed at the implementation and updating of crosscultural competence, at adequate cross-cultural communication in the context of the dialogue of cultures as wel and one of personality's trait, which consists of three components: culturally defined knowledge, adaptive communicative skills and. as a consequence of the ability to intercultural communication (V. Hryshenko) ${ }^{26}$.

- the common feature of the individuality, which manifests awareness and understanding of his own culture and foreign culture, as well, via a steady interest to multicultural values, the ability to act as an intermediary between representatives of different cultures, the ability to determine the causes of violations of intercultural communication and the ability to overcome the communicative barriers which arise because of crosscultural gaps (Ya. Sadchykova) ${ }^{27}$.

In the process of studying English defines business linguistic and sociocultural components of foreign communication competence. In the opinion of the scientist they consist of numerous verbal stereotypes and realities, the assimilation of which is necessary for business

23 Чеботарьова. I.О. Комунікативна компетентність: теоретичний аспект. Наукові записки кафедри педагогіки. Випуск XXXVI. Харків, 2014. С. 205-215.

24 Бермус А.Г. Проблемы и перспективы реализации компетентностного подхода в образовании. Интернет-журнал «Эйдос». 2005. URL: http://eidos.ru /journal/2005/0910-12.htm.

25 Засєкіна Л.В. Мовна особистість в сучасному соціальному просторі. Соціальна психологія. 2007. № 5 (25). С. 82-89, с. 83.

26 Гришенко В.Д. Аспекты содержанпя обучения межкультурной коммуникации в языковом вузе. Вестник МГОУ. 2012. № 2. С. 79-84, с. 81 .

27 Садчикова Я.В. Формирование межкультурной компетентности студентов в процессе обу чения иностранному языку втехничесюм вузе : автореф. дис. ... канд. пед. наук : 13.00.08. Пенза, 2009. 23 с. 
communication in accordance with the norms adopted in a certain language and cultural society to regulate business relationships (in a professional direction (O. Tarnopolsky) ${ }^{28}$.

Scientists as consider the sociolinguistic competence: knowledge, skills and the ability to interpret and use linguistic units, texts and situations, taking into account linguistic and ethnographic realities and sociolinguistic generic, professional, national and territorial peculiarities of those, who speak ${ }^{29}$.

The social and cultural education is the key to successful formation of foreign language communicative competence, subjected to the implementation of the principle of didactic culture compliance, which involves the selection and implementation of the educational process of cultural material and forms the social and cultural basis of the teaching and learning complex in foreign language. The social and cultural competence is as the ability of an individual to demonstrate active and responsible livelihoods in society on the basis of democracy, humanism, tolerance, etc., through adequate understanding and respect to other languages (M. Maksymets) ${ }^{30}$.

The social and cultural competence is interpreted as:

- a system of representations about the main national traditions, customs and realities of the country, being studied, as well as, a system of skills and abilities to coordinate their behavior according to these knowledge (O. Kolomynova) ${ }^{31}$;

- the ability of a person to take into account knowledge of the social and cultural contexts of the country consciously in the process of foreign language communication. All components of social and cultural competence are interconnected through the concept of cultural and social contexts. Their mastery must take place in a comprehensive manner. If the context of culture involves knowledge of realities common to all the native speakers, then the social context is acceptance of the specific

28 Тарнопольский О.Б., Кожушко С.П. Методика обучения английскому язику для делового общения / Учебное пособие. Киев : Ленвит, 2004. 192 с., с. 34.

29 Бех П.І. 3 позицій комунікативної орієнтації. Іноземні мови в навчальних закладах. 2002. № 1-2. С. 34-40, с. 36.

${ }^{30}$ Максимець М. Формування соціокультурної компетенції у процесі вивчення іноземної мови. Вісник Львівського університету. Серія педагогічна. 2006. Випуск 21. С. 211-218.

Коломинова О.О. О формировании социокультурной компетенции у младших школьников. Іноземні мови. 1997. № 3. С. 39-41. 
social conditions of communication adopted in the country of the language being studied ${ }^{32}$;

- the level of understanding of the social and cultural context in the use of a foreign language, as well as the experience of communication and use of language in various socio-cultural situations (V. Safonova) ${ }^{33}$;

- an ability and willingness to use a set of social and linguistic, social and psychological, ethnographic and intercultural knowledge for reaching mutual understanding between individuals or groups who are representatives of different societies, linguistic means and within the social and cultural context of one of the parties (S. Amelina, L. Azzolini, N. Beniaminova) $)^{34}$.

Foreign language is taught not only as means of communication, but also as means of discovering another cultural world, comprehensive understanding of the complexity and multiplicity of the native language and national culture, national dignity and equality, means of public education, personal development, its individual cognitive abilities, social opportunities, cultural needs. The organization of the studying process must be provided in such a way in order foreign language must be represented as a phenomenon of the national culture of people, as a model of studying the world of these people ${ }^{35}$.

The socio-cultural competence consists of: 1) socio-cultural knowledge (information about the country of the language being studied, spiritual values of cultural traditions, including representatives of different ethnic groups, features of the national mentality of behaviour); 2) experience of communication (the choice of an acceptable style of communication, the correct interpretation of the phenomena of foreign culture); 3) personal attitude to the facts of culture (including the ability to overcome and resolve sociocultural conflicts in communication);

32 Ларіонова О.I. Особливості формування соціокультурної компетенції у немовному вузі на матеріалі іноземної мови. URL: http://www.rusnauka.com/ Page_ru.htm.

33 Сафонова В.В. Культуроведение в системе современного языкового образования. Иностранныле языки в школе. 2011. № 3. С. 17-24.

${ }^{34}$ Рамкова програма 3 німецької мови для професійного спілкування для вищих навчальних закладів України / С.М. Амеліна, Л.С. Аззоліні, Н.С. Беньямінова та ін. Київ : Ленвіт, 2006. 90 с., с. 10-11.

35 Липшиць Л.В. Формування соціокультурної компетентності майбутніх судноводіїв міжнародних рейсів у процесі вивчення англійської мови. Педагогічний альманах. 2012. Випуск 15. С. 178-182, с. 179. 
4) mastering the ways of using the language (correct use of nationallymarked linguistic units in speech in various spheres of intercultural communication, susceptibility to similarity and differences between native and foreign-speaking sociocultural fields) ${ }^{36}$.

The process of the social and cultural competence formation of intercultural communication skills, which are ensured and developed in the process of learning of a foreign language by students, become part of the student's outlook. When they derive linguistic and socio-cultural information. Social and cultural competence is realized in the process of solving a number of linguistic tasks such as analytical-reflexive, constructive, correctional activities. Knowledge and cognitive skills, practical skills, emotions and motivation, values and ethics, are distinguished among the components of competence.

The formation of social and cultural competence of students presupposes the availability of knowledge in the national-cultural peculiarities of the country's language, being studied, the norms of speech and infant behavior of its carriers and the their ability to behave themselves in accordance with these features and norms (A. Murzina, N. Chernukha) ${ }^{37}$.

Mastering of foreign language is inextricably linked with the mastery of the national culture, which involves not only the assimilation of cultural knowledge, but also the formation of the ability and readiness to understand the mentality of the speakers of the studied language, as well as the features of communicative behavior of the people of this country. Linguistic and cultural competence presupposes the mastery of the equivalent vocabulary (within the framework of the subjects studied, subjects of speech) and the ways of its transmission in the native language; background vocabulary, realities characteristic of the authentic texts used in the teaching process; ways of transferring the realities of the native language in a foreign language (within the framework of the topics studied, subjects of speech) (G. Tomakhin) ${ }^{38}$.

${ }^{36}$ Сысоев П.В. Культурное самоопределение личности в контексте диалога культур. Тамбов : изд-во ТГУ, 2001. 144 с.

37 Чернуха Н.М., Мурзіна А.В. Умови формування соціокультурної компетентності майбутніх учителів філологів. Вісник ЛНУ імені Тараса Шевченка. 2009. № 9 (172). С. 165-173, с. 167.

38 Томахин Г.Д. Реалии в языке и культуре. Иностранные языки в школе. 1997.

№ 3. C. 13-15. 
In order to form social and cultural competence in the process of learning of foreign language, it is necessary to provide comfortable psychological and pedagogical conditions. Firstly, we can distinguish the creation of social and cultural educational environment; the establishment of human interpersonal relations on the dialogical basis of bilingual communication; the simulation of professionally oriented games; the use of innovative methods, in particular, communicative games. ${ }^{39}$

The communicative competence of a specialist is understood as a socially significant indicator of the level of communicative knowledge, language abilities as well as skills and ability to carry out professional dialogue, to perceive, to understand, to master the content of information, to establish feedback with the interlocutor, to solve specific tasks in professional sphere.

The communicative competence maturity is determined by the following indicators: the ability to understand phonetic and grammatical features of the target languages; the expedient use of language and communicative structures; the desire to improve their own language; the availability of cognitive and communicative needs; the effectiveness of the linguistic and language knowledge; the observance of phonetic, lexical, grammatical and stylistic norms in written and spoken language, the desire and ability to achieve the desired communicative goals.

\section{The pedagogical conditions of development of the intercultural communicative competence of pupils in the process of the study of foreign language}

The ability of a word to call a notion makes it possible to use a relatively small amount of words in the course of communication. Awareness of the inextricable connection of the word and concept is a guarantee of a successful profound mastery of the language, the ability to accurately express thoughts, finding the appropriate vocabulary for this. To the main characteristics of expressive Language enlist: breathing, voice, diction (pronunciation), intonation (tone), pace, etc. And only the proper mastering of each component of broadcasting

${ }^{39}$ Polyezhayev Y., Brutman A., Mantulo N. The Formation of Social and Cultural Competence of Future Journalists in the Process of the Study of Foreign Language: Theoretical Aspects. Педагогіка формування творчої особистості у вищій i загальноосвітній школах: зб. наук. пр. / редкол.: Т. І. Сущенко (голов. ред.) та ін. Запоріжжя : КПУ. 2017. № 56-57 (109-110). С. 441-449. 
technology can guarantee the high level of Language culture. The formation of social and cultural competence in the process of learning of foreign language is aimed at mastering not only the language of another country, but it is also oriented to the culture of communication with native speakers in certain conversations; to the assimilation of the system of national and universal values by students; to tolerant attitude to the cultural values of other peoples, to national culture of different countries of the world; to awareness of their national significance; to a manifestation of respect for the cultural heritage of his native country.

The primary role in the individual active vocabulary belongs to words and concepts. The word materializes the concept and forms it, and thus makes the word accessible for perception and assimilation ${ }^{40}$.

The study of new concepts consists of: a) enriching the vocabulary, that is, the assimilation of new words or new meanings of known words; b) refinement of the dictionary, that is, the introduction of individual words into the context, the comparison of the close or opposite of the meaning of words, the assimilation of multi valued and emotionally colored words; c) the dictionary activation, that is, transferring as many words as possible to the passive vocabulary (the student knows the meaning of the word, but seldom or does not use them at all) into the active; d) elimination of nonliterary words: dialectic, jargon, spatial, etc ${ }^{41}$.

The effectiveness of the acquisition of vocabulary and terminology by students depends on the organizational and pedagogical conditions: considering the communicative needs during the selection of terms for active learning; the selection of such methods and methods of training that will promote the enrichment of the active vocabulary; the development of a system of exercises aimed at the gradual, conscious and profound learning by the pupils terminology units; ensuring the teaching of scientific terminology by appropriate methodological developments; the creation communicative environment in a establishment of education; etc.

The scientist V. Makhinov ${ }^{42}$ offers the author's system of social and cultural communicative tasks which can be expressed in the following

40 Мацько Л.І., Мацько О.М. Риторика: навчальний посібник. Київ : Вища школа, 2003. $311 \mathrm{c}$.

41 Деркач А.А. Акмеология. Санкт-Петербург : Питер, 2003. 256 с.

42 Махінов В. Моделювання соціокультурних комунікативних завдань як засобу формування мовної особистості майбутнього вчителя. URL: https://www.narodnaosvita.kiev.ua/Narodna_osvita/vupysku/15/statti/mahinov. 
instructions as tasks for investigations: a) Say what differences and similarities you can see between the Ukrainian and British tradition of ...; b) Say if any Ukrainian musician had a tragic fate as John Lennon had; c) Look at sights and say where you can come across them in London. Draw similar sights common for Ukraine; d) Look at the sights and guess which of them are likely to be seen at the British Museum. Say what rules they express. How are similar rules expressed in a Ukrainian museum.

The methods of interactive learning are based on the mutual implementation of problem-oriented tasks by participants of the educational process, which are originally accompanied by foreignlanguage communication. It makes communicative interaction of all participants professionally significant and motivationally backed up. Organization of group forms of work, such as role-playing and businessoriented forms of games, training discussions, round-talk discussions, training, etc., in the process of foreign language activity develops the ability to express their point of view in order to solve a particular production problem, the ability to interpret facts or statistical information, the ability to predict the course follow up actions, the ability to assess the situation through the prism of their own experience and make the right decision. The pragmatic component of interactive learning is the formation of internal motivation in order to master the course of a professionally oriented foreign language, taking into account the crosscultural features of foreign communication. In addition interactive training updates the complex of professional knowledge and skills of students, forms such skills as readiness to adapt in new envi ronment, the ability to innovate thinking, creativity, responsibility (Y. Semenchuk ${ }^{43}$.

Researches interactive learning is a process of interpersonal communication in educational settings, which is characterized by a high degree of intensity of communication, variety of forms, forms and methods of activities, purposeful reflection and the interaction of participants in the pedagogical process (S. Kashlev) ${ }^{44}$.

In order to form social and cultural competence in the process of studying of foreign language, it is expedient to use IT systems, which actively implemented at the Classic Private University (Zaporizhzhia,

${ }^{43}$ Семенчук Ю.О. Інтерактивні технології у формуванні соціокультурної компетентності майбутніх економістів-міжнародників. Наукові записки. Сер. : Філологічна. Острог : Вид-во НУ «Острозька академія». 2014. Вип. 42. С. 230-232.

44 Кашлев С.С. Интерактивные методы обучения педагогике. Минск Вышэйшая школа, 2004. 176 с., с. 38. 
Ukraine). For example, there was created a virtual audience based on the Moodle platform. This platform provides learning through the using the electronic teaching and methodical complexes of disciplines.

Methodological and technical support of the work of the electronic Internet-resource is provided by the «Institute of Information Technologies in Education» of the University. The main tasks of this «Institute» is organizational, methodological and technical of the educational process; provision of round-the-clock work of servers and channels of the university on the Internet; technical support of work of the information systems, computer classes and the corporate computer network of the Classic Private University.

Systematized electronic teaching and methodical complexes of departments and institutes disciplines are available on the site of the electronic support of the educational process (Virtual auditorium) of the University. The structured teaching and methodological support that corresponds with module technology of teaching is represented according to the curricula of the specialties (in particular, teachers of a foreign language).

Accordingly, our university has created an informational educational and professional environment, which:

- contains electronic resources for each discipline of the curriculum for the preparing the specialists (in particular, future teachers of a foreign language) of a certain educational degree and specialty;

- provides students the opportunity to use educational content at any appropriate time;

- provides students (in particular, future teachers of a foreign language) teaching materials from all disciplines in order to fulfill individual and group tasks of innovative content;

- provides an intensive interaction of participants in the educational process;

- promotes the professional development and self-development of future specialists (in particular, teachers of a foreign language) and their involvement in the information educational and professional environment of the higher educational institution, created on the basis of the electronic portal that is based on the Moodle platform.

Using IT and new forms of organization the educational process in the educational institutions changes the teacher's functions. Teacher becomes 
not only the retransmitter but also an organizer of the educational process, a facilitator and a colleague in pedagogical cooperation.

The main advantages of using IT are:

1) providing students (in particular, future teachers of a foreign language) the complete information about professional preparation (curriculum and practical training curriculum, content of the curriculum, forms of final control, electronic educational materials of disciplines: lecture notes, electronic training manuals, individual tasks with methodological recommendations for their implementation; methods of intermediate control of disciplines, evaluation criteria for modules and electronic journals for evaluating student achievements);

2) elimination of duplication the contents of the educational material of different disciplines, quality control of the development of the electronic teaching and methodical complexes of disciplines and the quality of students' mastering of individual disciplines (heads of graduate departments, directors of institutes, vice-rectors of educational work have access to electronic teaching and methodical complexes, analyze the content of educational materials, timely adjust their content);

3) using the interdisciplinary cooperation (the focus of the content of all curriculum disciplines on vocational training, the implementation of interdisciplinary projects, the solution of complex integrated tasks of course, diploma and master's work);

4) providing students (in particular, future philology teachers) the possibility of designing their own trajectory of learning the disciplines (rates and sequencing of studying the theoretical material, performing individual and control tasks of different levels, planning educational and scientific work in an appropriate time due to access to the virtual audience through the Internet;

5) provision of pedagogical support (on-line consultations, forums, sending of messages via internal e-mail).

Thus, the use of a virtual foreign environment in the formation of socio-cultural competence among students of the non-philological profile leads to a qualitative change in the content of foreign language training. The implementation of foreign language training in a virtual educational environment contributes to the effective formation of sociocultural competence among students. In Web-based learning, students demonstrate a high level of foreign language motivation and culture, traditions and customs, critical thinking to evaluate their skills, 
participating in the group discussions. The educational autonomy of students provides a transition to the individualization of learning. A variety of electronic resources for teaching a foreign language opens up new opportunities for a polysensory presentation of educational material in a modern, accessible and interesting form. Using the potential of a virtual foreignlanguage educational environment in the process of teaching a foreign language based on the principle of flexibility and variability allows students determine independently the individual trajectory of learning foreign language, contributing to the formation of their sociocultural competence (V. Krasnopolskyi) ${ }^{45}$.

\section{CONCLUSION}

Taking into account the above-stated, it can be concluded that aor the purpose of development also advisable to use creative tasks, educational communicational games, simulative professional situations, the solution of which is aimed at developing special skills: comprehensive contextual understanding, retelling of the content, operating of synonymic and antonymic notions of language compression of texts, transformation of the grammatical structure of messages for oral expression during reporting, newsreels and interviews, etc. at classes. Considerable attention should be paid to the development of future teachers' skills: to be engaged into conversations, to be a party to bilingual communication, to navigate information freely, to find it, to process and distribute it promptly.

It should be noted that the modern conditions of teaching foreign languages, in order to form social and cultural competence in the process of learning of foreign language, it is necessary to provide comfortable psychological and pedagogical conditions. Firstly, we can distinguish the creation of social and cultural educational environment; the establishment of human interpersonal relations on the dialogical basis of bilingual communication; the simulation of professionally oriented games; the use of innovative methods, in particular, communicative games. Social support of linguistic behavior of individuality is also defined among the conditions for the development of creative abilities of a person.

${ }^{45}$ Krasnopolskyi V.E. Formation of sociocultural competence of students in the virtual foreign language education environment. Духовність особистості: методологія, теорія і практика. 2018. № 2 (83). С. 75-85, с. 82. 
One of the important tasks in modern education is the development of creative initiative and independence of pupils, the formation of their social and cultural competence. The application of innovative pedagogical methodic contributes to the formation of critical and creative thinking of pupils (as the central mechanism for the generation of new ideas), the rapid adoption of their independent decisions. The use of interactive teaching methods stimulates cognitive activity of pupils, development of their communicative skills; predetermines successful fulfillment of creative tasks; promotes pedagogical cooperation and equal dialogue of the teacher with pupils. In order to improve speech skills, one must understand the essence of speech and language as a means of communication, knowledge of the peculiarities of the perception of oral speech.

\section{SUMMARY}

The article deals the teretic aspects of communicative, intercultural and sociocultural competence. Methodical tools are revealed and practical recommendations are presented concerning the training of future philology teachers to form communicative and intercultural competence in students in the process of learning a foreign language. The pedagogical conditions for the formation of social and cultural competence among future teachers of a foreign language in the process of professional training are determined. It is emphasized that creation of social and cultural educational environment and the establishment of human interpersonal relations on the mutual understanding basis of multilingual communication are of great importance. Noted that formation of the social and cultural competence of future philology teachers in the process of studying a foreign language is aimed at mastering not only the language of another country, but also the culture of communication of native speakers. An example is given of how a virtual audience was created on the basis of the Moodle platform, where learning is being conducted with the help of electronic teaching and learning complexes on disciplines.

\section{REFERENCES}

1. Соломаха А.В. Взаємозв'язок світу, етносу та мови (до питання про мовну картину світу). Науковий часопис НПУ ім. 
М.П. Драгоманова. Серія № 8. Філологічні науки (мовознавство $і$ літературознавство). 2005. Вип. 1. С. 117-121.

2. Леонтьев А.А. Психолинвистика и личность. Основы психолингвистики. Санкт-Петербург, 2003. С. 280-282.

3. Великий тлумачний словник сучасної української мови / уклад. і голов. ред. В.Т. Бусел. Київ; Ірпінь : ВТФ «Перун», 2009. $736 \mathrm{c.}$

4. Зимняя И.А. Ключевые компетентности как результативноцелевая основа компетентностного подхода в образовании. Москва: Исследовательский центр проблем качества подготовки специалистов, 2004. 40 с.

5. Карасик В.И. Речевое поведение и типы языковых личностей. Массовая культура на рубеже XX-XXI веков: Человек и его дискурс. Москва: Азбуковник, 2003. 368 с.

6. Куницына В.Н., Казаринова Н.В., Погольша В.М. Межличностное общение : учебник для вузов. Санкт-Петербург : Питер, 2001. 544 c., c. 9.

7. Компетентнісний підхід у сучасній освіті: світовий досвід та українські перспективи / за заг. ред. О.В. Овчарук. Київ : «K.I.C.», 2004. 112 c.

8. Боднар С.П. Термінологічний аналіз понять «компетенція» $\mathrm{i}$ «компетентність» у педагогіці: сутність та структура. Oсвіта $i$ управління. 2007. Т. 10. № 2. С. 93-99.

9. Зимняя И.А. Ключевые компетентности как результативноцелевая основа компетентностного подхода в образовании. Москва : Исследовательский центр проблем качества подготовки специалистов, 2004. 40 с.

10. Кенжебеков Б.Т. Сущность и структура профессиональной компетентности специалиста. Высшая школа Казахстана. 2002. № 2. C. 171 .

11. Татур Ю.Г. Компетентностный подход в описании результатов и проектировании стандартов высшего профессионального образования. URL: http://technical.bmstu.ru/istch/komp/ tatur_II.psd.

12. Маркова А.К. Психология профессионализма. Москва : Знание, 1996. 308 с., с. 31.

13. Настільна книга педагога / упорядники: Андрєєва В.М., Гигораш В.В. Харків : Основа, 2006. 352 с. 
14. Професійна освіта: словник / уклад. С.У. Гончаренко та ін. / за ред. Н.Г. Ничкало. Київ, 2000. 380 с.

15. Зязюн І.А. Філософія поступу і прогнозу освітньої системи. Педагогічна майстерність : проблеми, пошуки, перспективи : монографія. Київ : Глухів : РВВ ГАПУ, 2005. С. 10-18.

16. Бех І.Д. Особистісно-зорієнтоване виховання : навч.-метод. посіб. Київ : ІЗМН, 1998. 204 с.

17. Жуков Ю.М. Тренинг как метод совершенствования комуникативной компетентности : дисс. д-ра психол. наук : 19.00.05. Москва, 2003. 356 с.

18. Хуторской А.В. Ключевые компетенции как компонент личностно-ориентированной парадигмы образования. Народное образование. 2003. № 2. С. 58-64.

19. Черезова I.О. Комунікативна компетентність як інтегральна якість особистості. Науковий вісник Херсонського державного університету. Серія: «Психологічні науки». 2014. Вип. 1. Т. 1. C. $103-107$.

20. Основы теории коммуникации : учебник / под ред. М.А. Василика. Москва : Гардарики, 2003. 615 с.

21. Tinsley Royal L. Guidelines for college and University programs in translator training. URL: http://www.adfl.org/cgishl/docstudio/ docs.pl?adfl_login\&xurl.

22. Емельянов Ю.Н. Теория формирования и практика совершенствования коммуникативной компетентности. СанктПетербург, 1999. 403 с.

23. Чеботарьова. I.O. Комунікативна компетентність: теоретичний аспект. Наукові записки кафедри педагогіки. Випуск XXXVI. Харків, 2014. С. 205-215.

24. Бермус А.Г. Проблемы и перспективы реализации компетентностного подхода в образовании. Интернет-журнал «Эйдос». 2005. URL: http://eidos.ru /journal/2005/0910-12.htm.

25. Засєкіна Л.В. Мовна особистість в сучасному соціальному просторі. Соціальна психологія. 2007. № 5 (25). С. 82-89.

26. Гришенко В.Д. Аспекты содержанпя обучения межкультурной коммуникации в языковом вузе. Вестник МГОУ. 2012. № 2. С. $79-84$.

27. Садчикова Я.В. Формирование межкультурной компетентности студентов в процессе обу чения иностранному языку 
втехничесюм вузе : автореф. дис. ... канд. пед. наук : 13.00.08. Пенза, 2009. 23 с.

28. Тарнопольский О.Б., Кожушко С.П. Методика обучения английскому язику для делового общения / Учебное пособие. Киев : Ленвит, 2004. 192 с.

29. Бех П.І. 3 позицій комунікативної орієнтації. Іноземні мови в навчальних закладах. 2002. № 1-2. С. 34-40.

30. Максимець М. Формування соціокультурної компетенції у процесі вивчення іноземної мови. Вісник Львівського університету. Серія педагогічна. 2006. Випуск 21. С. 211-218.

31. Коломинова О.О. О формировании социокультурной компетенции у младших школьников. Іноземні мови. 1997. № 3. С. 39-41.

32. Ларіонова О.I. Особливості формування соціокультурної компетенції у немовному вузі на матеріалі іноземної мови. URL: http://www.rusnauka.com/Page_ru.htm.

33. Сафонова В.В. Культуроведение в системе современного языкового образования. Иностранные языки в школе. 2011. № 3. C. $17-24$.

34. Рамкова програма 3 німецької мови для професійного спілкування для вищих навчальних закладів України / С.М. Амеліна, Л.С. Аззоліні, Н.С. Беньямінова та ін. Київ : Ленвіт, 2006. $90 \mathrm{c}$.

35. Липшиць Л.В. Формування соціокультурної компетентності майбутніх судноводіїв міжнародних рейсів у процесі вивчення англійської мови. Педагогічний альманах. 2012. Випуск 15. C. $178-182$.

36. Сысоев П.В. Культурное самоопределение личности в контексте диалога культур. Тамбов : изд-во ТГУ, 2001. 144 с.

37. Чернуха Н.M., Мурзіна А.В. Умови формування соціокультурної компетентності майбутніх учителів філологів. Вісник ЛНУ імені Тараса Шевченка. 2009. №9 (172). С. 165-173.

38. Томахин Г.Д. Реалии в языке и культуре. Иностранные языки в школе. 1997. № 3. С. 13-15.

39. Polyezhayev Y., Brutman A., Mantulo N. The Formation of Social and Cultural Competence of Future Journalists in the Process of the Study of Foreign Language: Theoretical Aspects. Педагогіка формування творчої особистості у вищій $i$ загальноосвітній 
школах: зб. наук. пр. / редкол.: Т. І. Сущенко (голов. ред.) та ін. Запоріжжя : КПУ. 2017. № 56-57 (109-110). С. 441-449.

40. Мацько Л.І., Мацько О.М. Риторика: навчальний посібник. Київ : Вища школа, 2003. 311 с.

41. Деркач А.А. Акмеология. Санкт-Петербург : Питер, 2003. $256 \mathrm{c}$.

42. Махінов В. Моделювання соціокультурних комунікативних завдань як засобу формування мовної особистості майбутнього вчителя. URL: https:/www.narodnaosvita.kiev.ua/Narodna_osvita/ vupysku/15/statti/mahinov.

43. Семенчук Ю.О. Інтерактивні технології у формуванні соціокультурної компетентності майбутніх економістівміжнародників. Наукові записки. Сер.: Філологічна. Острог : Вид-во НУ «Острозька академія». 2014. Вип. 42. С. 230-232.

44. Кашлев С.С. Интерактивные методы обучения педагогике. Минск : Вышэйшая школа, 2004. 176 с.

45. Krasnopolskyi V.E. Formation of sociocultural competence of students in the virtual foreign language education environment. Духовність особистості: методологія, теорія і практика. 2018. № 2 (83). С. 75-85.

\section{Information about the author: Diachenko M. D.}

Doctor of Pedagogic Sciences, Professor of Department of Theory and Practice of Translation, Classic Private University 70-B, Zhukovsky str., Zaporizhzhia, 69002, Ukraine 